\title{
The Empirical Research of University-Enterprise Cooperation Education for Training Applied Talents - Taking a University in Shanghai as An Example
}

\author{
Yuanjun Sun \\ School of Management, Shanghai University, Shanghai, P.R.China
}

Keywords: University-enterprise cooperation, Applied talents, Private colleges

Abstract. University-enterprise cooperation is an effective way for private colleges to train applied talents. University-enterprise cooperation is not only a kind of education behavior, also a kind of economic behavior. Private colleges get rapid progress in collaborative innovation. From the nurturing mode of university-enterprise cooperation connotation, this paper illustrates the necessity for private colleges to implement 'uni-versity-enterprise cooperation' training mode.

\section{University-enterprise Cooperation Education}

1.1 Background. National Medium- and Long-Term Plan for Education Reform and Development proposes the corresponding system of laws and regulations to promote university-enterprise cooperation. For the completion of the practice teaching tasks, enterprises should actively cooperate with the cooperation colleges, providing technology and capital as much as possible. Enterprises help the university to complete the talent training. There is no doubt that the university-enterprise cooperation has become the important characteristics of education development in our country.

1.2 Concept. There is no doubt that university-enterprise cooperation establishes a cooperative mode. It is a kind of the form that jointing between universities and enterprises carries out the talents cultivation in the process of cooperation closely together. The college is an organic combination of education and practical education to cultivate high-quality talents of meeting the needs of the enterprise of a form of education.

1.3 Training Mode. University-enterprise cooperation refers to participate in the university personnel training. It has become a part of the enterprise mission, and the participation of enterprise personnel training in universities is a comprehensive range of participation. It also implements the integration management administration. Enterprise can take equipment, technology, and other forms to the colleges and universities. It can not only cultivate talents for oneself, also share the profit. Therefore, this is also the goal of university-enterprise cooperation purposefully, with training students achievement - practice.

\section{Applied Talents}

2.1 Implication. The important mission of cultivating applied talents is run by the local colleges. It is good at corresponding to the actual operation of skilled talents, both enough theoretical basis and professional. And it also can integrate theory with practice. Applied colleges and universities should be clear to the students employment as the guidance. The local undergraduates cultivate applied talents with broad knowledge of theory. At the same time, it can be able to transform the corresponding theory knowledge in the practice innovation ability.

2.2 Characteristics. From the point of view of characteristic: applied talents in the aspect of knowledge, ability and quality get all-round development. It emphasizes on founding problems, practical application ability to analyze and solve problems.

From the point of view of social function and value: applied talents emphasis on the development of economy and society and direct correspondence. It can emphasize the social adaptation ability and service consciousness, with the social needs and seamless docking ability. 
2.3 Orientation of the Cultivating. At the university of applied technology, talents training target is geared to the needs of regional economic and social development needs. Training does not only pay attention to the knowledge, but also apply theory to practice in the senior applied talents. On the service oriented, service is for local economic construction and social development. Applied talents are mainly guided by certain theoretical specification and applying knowledge to practice.

\section{The Empirical Research}

\subsection{The Introduction of A Private College}

3.1.1 Basic Information. In June 1992, the University, as a full-time private university, was founded by professors from Shanghai Jiaotong University, Peking University and Tsinghua University. The university has two campuses, one in the Pudong District of Shanghai and the other in Jiashan County, Zhengjiang Province, with a total area of $808 \mathrm{Mu}$ (about 133 acers). The University was the first full-time private university of ever approved in China since the restructuring of universities in 1952. In March 2002, officially approved by the Ministry of Education, A University became the first private comprehensive university in Shanghai providing full-time four-year undergraduate programs, under the supervision of Shanghai Municipal Government. From 2003 to 2015, the university has been established under the guidance of companies. They have served to consolidate our integration into social and economic development. Our graduates have been well recognized by society. The purpose is to improve its teaching administration and evaluation procedures and develop an effective system for educating, through university-enterprise joint research programs and international cooperation, in order to train high-quality, creative and application-oriented students.

Since its foundation, the University has adhered to the principles of non-profitness and benefiting the public. No organizations and individuals shall have possession of its property. A is also committed to ensuring fair education opportunities and giving priority to equality teaching and school spirit construction.

3.1.2 Present Situation of University-enterprise Cooperation. The University adheres to industry-university cooperative education, optimizing personal training mode and building the industry-university cooperation with various forms and implementing flexibility through cultivation programs and teaching operation.

It now has 1 national college off-campus practice base and 1 Shanghai Innovative Entrepreneurship Education Experiment Base. Through university-enterprise cooperation, it has established 106 off-campus practice bases, and 106 university experiment training rooms. They collaborated with the schools in course design and education development to train students for their professional skills.

\subsection{Existing Problems}

3.2.1 System Problems. Without a strong system guarantee, the government has not formulated the corresponding preferential tax and cost compensation policy. The second is the candidates , and it failed to make full use of its advantages in system and mechanism of choosing and employing persons. It failed to form a long-term development mechanism. To further support of cooperation between colleges and the further university-enterprise cooperation degree, the function of colleges and enterprises, between universities and enterprises gradually form a long-term mechanism of cooperation.

3.2.2 Management Problems. Management is not strong enough. In university-enterprise cooperation effect evaluation of colleges and universities, students participate in aspects such as the cognizance of university-enterprise cooperation credits has certain difficulty. There is an important factor affecting the university-enterprise cooperation to deepen. On major course development and enterprise standards are to solve the school personnel training specification as soon as possible .It does not accord with market requirements of structural contradictions, truly achieve switching between colleges and enterprises.

3.2.3 Operating Problems. The operation mechanism of university-enterprise cooperation is not clear enough. It is an effective method of enterprise human resources development talent and 
jointing participation when students are in the job training of the enterprise. It clearly puts forward the rights, responsibilities of both parties, on the basis of equality and mutual benefit.

\subsection{Statistical Analysis}

3.3.1 Correlation Analysis. According to the present situation of the university, the author has carried on the investigation to the problem analysis. After investigation, the school of university-enterprise cooperation behavior of two dimensions and enterprise university-enterprise cooperation behavior of the correlation between two dimensions are as follows. Factors: (1) the school behavior of university-enterprise cooperation in two dimensions and enterprises were significantly positive correlation, the correlation coefficient respectively is school talent training input $(\mathrm{r}=0.440 * *)$, school cooperation input $(\mathrm{r}=0.636 * *) ;(2)$ the school was significantly positively related with the process of knowledge acquisition, the correlation coefficient respectively for school personnel training input $(\mathrm{r}=0.559 * *)$, school cooperation input $(\mathrm{r}=0.444 * *)$.

All in all, throughout the questionnaire of each variable, it has a significant correlation between each dimension, and specific information is as follows (Table 1).

Table 1. The descriptive analysis of enterprise university-enterprise cooperation behavior.

\begin{tabular}{lllll}
\hline Item & $\begin{array}{l}\text { Averag } \\
\mathrm{e}\end{array}$ & SEM $^{*}$ & SD* & Statistics \\
\hline $\mathrm{A}^{*}$ & 3.14 & .048 & 1.108 & 635 \\
$\mathrm{~B}^{*}$ & 3.16 & .053 & 1.236 & 635 \\
$\mathrm{C}^{*}$ & 3.60 & .041 & 1.066 & 635 \\
$\mathrm{D}^{*}$ & 3.2842 & .03756 & .87463 & 635 \\
$\mathrm{E}^{*}$ & 3.3572 & .02765 & .75476 & 635 \\
\hline
\end{tabular}

* A: companies involved in the curriculum construction in schools; B: provide students with practical training equipment enterprises; $\mathrm{C}$ : companies to provide employment opportunities for the students; D: the average of the Enterprise university - enterprise cooperation; E: enterprise personnel training in average; SEM: standard error of the mean; SD: the standard deviation.

Compared with the behavior of the University-enterprise cooperation, it can be seen that the enterprise is in the aspect of talent cultivation of average of 3.3572. It is significantly higher than 3.2842, and enterprises invest in the cooperation between colleges and the rise of space.

3.3.2 Validity Analysis. In order to guarantee the quality of the data, it is necessary to carry out the questionnaire validity and reliability test. It ensures that each of the two tables is measured the appropriateness and adequacy of the concept. According to the characteristics of the small difference between the data, factor analysis of the data keeps three decimal point specific as follows (Table 2)

Table 2. The results of exploratory factor analysis

\begin{tabular}{|c|c|c|c|c|c|c|}
\hline $\begin{array}{l}\text { Analysis } \\
\text { object }\end{array}$ & Factor & Item content & $\begin{array}{l}\text { Load } \\
\text { factors }\end{array}$ & $\begin{array}{l}\text { The } \\
\text { eigenval } \\
\text { ue }\end{array}$ & $\begin{array}{l}\text { Explaini } \\
\text { ng } \\
\text { variance } \\
\%\end{array}$ & $\begin{array}{l}\text { Cumulative } \\
\text { explain } \\
\text { different } \\
\text { amount } \\
\text { of } \%\end{array}$ \\
\hline \multirow{2}{*}{$\begin{array}{l}\text { University- } \\
\text { enterprise } \\
\text { cooperation } \\
\text { behavior in } \\
\text { school }\end{array}$} & $\begin{array}{l}\text { 1. Talent } \\
\text { training in }\end{array}$ & $\begin{array}{l}\text { Universityl } \\
\text { teachers } \\
\text { teach } \\
\text { knowledge, } \\
\text { skill level }\end{array}$ & .838 & 2.925 & 36.565 & 36.565 \\
\hline & $\begin{array}{l}\text { 2.Universit } \\
\mathrm{y} \text { - } \\
\text { enterprise } \\
\text { cooperation } \\
\text { in }\end{array}$ & $\begin{array}{l}\text { In the } \\
\text { university } \\
\text { curriculum } \\
\text { training content } \\
\text { from the } \\
\text { enterprise } \\
\text { reality }\end{array}$ & .810 & 2.541 & 31.745 & 68.322 \\
\hline
\end{tabular}


Table 2, cont.

\begin{tabular}{|c|c|c|c|c|c|c|}
\hline \multirow{2}{*}{$\begin{array}{l}\text { Enterprise } \\
\text { university- } \\
\text { enterprise } \\
\text { cooperation } \\
\text { behavior }\end{array}$} & $\begin{array}{l}\text { 1. Talent } \\
\text { training in }\end{array}$ & $\begin{array}{l}\text { The enterprises } \\
\text { to provide } \\
\text { employment } \\
\text { opportunities } \\
\text { for the students }\end{array}$ & .793 & 2.344 & 23.435 & 59.322 \\
\hline & $\begin{array}{l}\text { 2.Universit } \\
y- \\
\text { enterprise } \\
\text { cooperation } \\
\text { in }\end{array}$ & $\begin{array}{l}\text { Enterprises } \\
\text { provide training } \\
\text { equipment for } \\
\text { the school }\end{array}$ & .790 & 3.589 & 35.887 & 35.887 \\
\hline
\end{tabular}

From the point of exploratory factor analysis results, all items of factor loading were significantly higher than the amount that experts suggest 0.6 minimum critical level, but also has the very strong statistical significance $(p<0.001)$, the school is fully illustrated university-enterprise cooperation behavior of cooperation between colleges and enterprises behavior formal questionnaires are strong inside collect validity.

In a word, through the analysis of university-enterprise cooperation between the two, you can clearly see institutions and enterprise of the relationship between cooperation space, of the relationship between universities and enterprises closely, top of the correlation between the relationship between universities and enterprises, is worth us to think about, is worth for us to implement.

\section{Countermeasure}

4.1 To Establish and Improve the System of University-enterprise Cooperation. To establish the colleges of cooperation mechanism, the first is the innovation of university-enterprise cooperation. Currently, it in Shanghai needs try to promote the collaborative innovation of industry-university-research cooperation, which is the shortcut of enhancing the competitive force as well as the effective way to blend Colleges and universities and scientific research units into the construction of an innovative country. The second is to set up the system of Science and Technology Correspondent, making teachers themselves or scientific and technological achievements into the enterprise, which can directly bring benefit to society. Through tripartite joint efforts by the government, schools and enterprises, we can construct university-enterprise cooperation platform.

4.2 To Start with University-enterprise Cooperation for the Social Service, Perfect the Pattern of Industry-enterprise Cooperation. In cooperation with the service in support, it focuses on completing some projects .It promotes university-enterprise cooperation in running schools, cultivating fashion capital construction needs of professional and technical personnel and results. It explores the industry technology, talent and resources advantages, and the fusion of running a school education system of mutually beneficial win-win mechanism.

4.3 Implementation of the 'Social Service Promotion Plan', the Establishment of Production, with the System. Universities improve the incentive mechanism of scientific research and establish interdisciplinary collaborative research platform. The university has established more than 160 off-campus practice teaching base, and the selection field 28 co-operative education demonstration base, hire part-time (deputy) professor in the department of production 45 people, greatly enhance the ability of social services, 'lead enterprise enter the' construction of productive practice base.

\section{Conclusion}

University-enterprise cooperation is a direction of the local education reform and practice . Based on the University-enterprise cooperation, fully exploiting industry technical superiority, talent advantage and resource advantage is urgent, which can promote the construction of a school education system of mutually beneficial win-win mechanism; relying on university-enterprise 
cooperation projects, we need expand the "Double Card Accommodation" curriculum system, and explore the integration education mode of talents cultivation, applied research, social service.

We should actively explore the running school path of the cooperation with well-known foreign colleges and the international cooperation of foreign-related enterprises. University-enterprise cooperation can revitalize the education inventory assets, enrich the connotation of the professional, and expand the field of dock with the local economy, developing into the school-running characteristics and in a further step, cultivating a new growth point of private schools education.

\section{References}

[1] Cedercreutz K, Cates C. Cooperative Education at the University of Cincinnati: A Strategic Asset in Evolution.[J] Peer Review. 2010, 12(4): 20-23.

[2] Chesbrough, H.W. The logic of open innovation: Managing intellectual property [J]. California Management Review, 2013, 23(6): 45-56.

[3] Hyslop A. Lessons form the German Dual System.[J] Techniques: Connecting Education \&Careers. 2012, 87(8): 40-45.

[4] Faggian, A., McCann, P. Human capital, graduate migration and innovation in British regions [J]. Cambridge Journal of Economics, 2011, 16(5): 158-179.

[5] Fifolt M, Searby L. Mentoring in Cooperative Education and Internships: Preparing Proteges for STEM Professions. [J] Journal Of STEM Education: Innovations \& Research. January 2010, 11(1): 17-26. 